\title{
Microsatellite Variation Within Three Populations of Inbred C57BL/6J Strain
}

\author{
NIU Yi-dong ${ }^{1, ~ *}$, LIANG Shu-long ${ }^{2}$ \\ (1. Laboratory Animal Center, Peking University People's Hospital, Beijing 100044, China; 2. School of Basic Medical Sciences, \\ Peking University, Beijing, 100191, China)
}

\begin{abstract}
The goal of this study was to investigate the genetic stability of the C57BL/6J (B6) inbred mouse strain maintained in different breeders. Three populations of B6, Pop1 and Pop2 purchased from Beijing and Pop3 purchased from Shanghai, were examined. Fifteen microsatellite loci reported to be polymorphic among inbred strains were amplified using FAM labeled primers and genotyped with ABI Prism 377 automated sequencer. Seven loci were found polymorphic, and all the loci were homozygous in all the three populations. The present study indicates that genetic variation occurs in different B6 populations although they are still inbred in each breeder. The mechanism of genetic variation is not well understood now, but it is very important to know the precise content of the B6 genome before use of this strain in research.
\end{abstract}

Key words: C57BL/6J strain; Microsatellite locus; Genetic variation

\section{三个近交系 C57BL/6J 小鼠群体微卫星遗传变异分析$$
\text { 牛屹东 }{ }^{1,} \text {, 梁蜀龙 }{ }^{2}
$$ \\ (1. 北京大学人民医院 实验动物中心, 北京 100044; 2. 北京大学 基础医学院, 北京 100191)}

摘要: 应用微卫星遗传标记对近交系 C57BL/6J（B6）小鼠遗传稳定性进行分析。用 FAM 标记的引物 PCR 扩 增了来自北京和上海三个实验动物生产单位提供的三个 B6 小鼠群体共 15 个微卫星位点并进行分型。结果显示, 所有位点均处于纯合状态, 其中 7 个位点为多态位点。研究表明各 B6 群体虽然为高度近交群体, 但不同生产单 位维持的 B6 群体之间存在遗传分化。

关键词: C57BL/6J 品系; 微卫星位点; 遗传变异

中图分类号: Q31; Q347; Q95-331 文献标识码：A 文章编号: 0254-5953-(2008)06-0599-04

The well established inbred C57BL/6J (B6) mice were widely used in bio-medical, especially metabolic and related disorder studies throughout the world, and introduced into many different countries during the last century. They have been maintained in those countries for different span of time. Few doubt the stability of the genetic background of B6 in their studies, although specific genetic differences have been found among B6 substrains (Specht \& Schoepfer, 2001). Furthermore, recent study indicates that even the most carefully maintained inbred strains carry genetic differences (Watkins-Chow \& Pavan, 2008).
In our previous study on type 2 diabetes, B6 presented unexpected fluctuation of body weight and levels of blood glucose, although the protocol followed the standard descriptions (Niu et al, 2007). We do not agree on the general simple opinion that abnormal phenomena are resulted from environmental, epigenetic, or stochastic differences (Crabbe et al, 1999; Burcelin et al, 2002; de Fourmestraux et al, 2004), because no reliable genetic detection were performed. Many findings indicate that the contribution of inbred strain genetic background to the phenotype is an important factor to consider when designing and interpreting experiments

Received date: 2008-07-24; Accepted date: 2008-10-22

Foundation item: Supported by Peking University People’s Hospital Research and Development Foundation (RDB2007-03)

*Corresponding author（通讯作者）, Tel: 86-10-88325991, E-mail: niuyd07@yahoo.com.cn

收稿日期：2008-07-24；接受日期：2008-10-22

基金项目：北京大学人民医院研究与发展基金（RDB2007-03） 
(Berglund et al, 2008).

The goal of the current study was to investigate the genetic stability among three B6 populations maintained by three respected commercial breeders in China. Fifteen microsatellite markers, which have been reported polymorphic among inbred mouse strains (Slingsby et al, 1995; Benavides et al, 2000; Li et al, 2001a, 2001b; Wang et al, 2006), were amplified by PCR and examined.

\section{Materials and methods}

\subsection{Animals}

The inbred B6 mice maintained in three commercial animal breeders (Pop1 and Pop2 from Beijing, and Pop3 from Shanghai, fifteen individuals for each population) in China were purchased at 4 weeks of age. Housing was temperature $\left(23 \pm 3^{\circ} \mathrm{C}\right)$ and humidity $(50 \% \pm 20 \%)$ controlled on a 12 hour light/dark cycle schedule according to the Chinese National Standard (GB14925-2001). The whole experiment was reviewed and approved by the Peking University People's Hospital Ethic Committee (Assurance No. FWA00001384).

\subsection{Extraction of genomic DNA}

Tail tissues were collected from the mice. Genomic DNA was extracted using the Gentra Puregene ${ }^{\circledR}$ Mouse Tail Kits (D-7010B).

\subsection{Selection of microsatellite loci and primers}

A total of 15 microsatellite loci (Tab. 1) reported to be polymorphic among inbred mouse strains were analyzed. The primers were procured from Sangon Inc. Shanghai China according to the data in MGI_4.01 (http://www.informatics.jax.org), and the forward or reverse primers for genotyping were labeled with FAM at the 5 ' ends (Tab. 1).

\subsection{Reaction conditions of PCR}

PCR reactions were performed in $25 \mu \mathrm{L}$ volume mixture containing 60 ng genomic DNA, $12.5 \mu \mathrm{L}$ Premix Taq $^{\text {TM }}$ (TaKaRa, DRR003A), $0.1 \mu \mathrm{mol} / \mathrm{L}$ forward and reverse primers. The reactions were performed in the MJ Research PTC-200 Peltier Thermal Cycler, starting with $94^{\circ} \mathrm{C}$ for $5 \mathrm{~min}$, followed by a touchdown PCR program. The program started with 5 cycles at high annealing temperatures $\left(62^{\circ} \mathrm{C}\right.$ and then $\left.60^{\circ} \mathrm{C}\right)$, followed by $25-30$ cycles at individual annealing temperatures (Tab. 1).

\subsection{Data analysis}

PCR products were resolved using an ABI Prism 377 automated sequencer, and analyzed using Genotyper v2.5 (Applied Biosystems). Genotypes were analyzed with the program MicroChecker 2.2.3 (Van Oosterhout et al, 2004) to estimate null allele frequency and other potential genotyping problems. Heterozygosity was estimated using POPGENE v1.32 (Yeh \& Boyle, 1997). A phylogenetic tree was constructed by UPGMA method based on the Nei's distance (Yeh \& Boyle, 1997).

\section{Results}

The size of those loci ranged from 92 to $256 \mathrm{bp}$. Seven loci were polymorphic and 8 loci were monomorphic among the three B6 populations (Tab.1), with no evidence for large allele dropout or null alleles. All the loci were homozygous.

In the UPGMA tree, the Pop1 (Beijing) and Pop3 (Shanghai) were included in one cluster which have diverged from the Pop2 (Beijing) for a long time (Fig. 1). However, the divergent time can not be calculated exactly because microsatellite loci of inbred strains evolve in different rate (Dallas, 1992), and we do not know accurately how many generations were produced every year by a pair of B6 mice in each breeder.

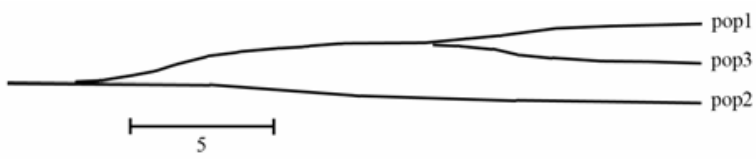

Fig. 1 UPGMA tree summarizing relationships among B6 populations maintained in three commercial animal breeders based on the Nei's genetic distance

\section{Disscussion}

The present study found that high level of microsatellite variation occurred within the inbred B6 strain, although they were still inbred among breeders. Repeated introduction of B6 colonies from different animal breeders is an important factor that may increase the risk of genetic mixture and contamination. The high deviation between the two Beijing populations (Pop1 and Pop2) may result from this operation or hybridization between different populations. Recent study indicates that a continuous and unavoidable flow of genetic variability does exist in the B6 strain (Casellas \& Medrano, 2008). Watkins-Chow \& Pavan (2008) also predicts that genetic variations could exist within the individual frozen embryo stock which was used to replace the foundation stock every five generations to limit the genetic drift in the Jackson Laboratory (Taft et al, 2006), and persist in the population independent of any possible selection. If it is true, knowledge of the 
Tab. 1 Microsatellite loci, primer sequences and annealing temperatures for genotyping

\begin{tabular}{|c|c|c|c|c|c|c|}
\hline \multirow{2}{*}{ No. } & \multirow{2}{*}{ Microsatellite locus } & \multirow{2}{*}{ Primers $\left(5^{\prime}-3 '\right)$} & \multirow{2}{*}{$\begin{array}{c}\text { Annealing } \\
\text { Temperature }\left({ }^{\circ} \mathrm{C}\right)\end{array}$} & \multicolumn{3}{|c|}{ Locus size (bp) } \\
\hline & & & & Pop 1 & Pop 2 & Pop 3 \\
\hline 1 & D2Mit51 ${ }^{* *}$ & $\begin{array}{l}{ }^{*} \text { GTGAGGGGTCAATGCCAC } \\
\text { GGCTCAGTTGTAAGCACAAGG }\end{array}$ & 57 & 123 & 127 & 127 \\
\hline 2 & D2Nds3 & $\begin{array}{l}{ }^{*} \text { CCAAGCTTCCTTGTGCAAGTA } \\
\text { AAGCCCAAAGTCCATCAGTGG }\end{array}$ & 59 & 256 & 256 & 256 \\
\hline 3 & D3Mit15 $^{* *}$ & $\begin{array}{l}{ }^{*} \text { AATTTGCATTCCAGGACCAC } \\
\text { AGGAAGTGACGTTGGGTTTG }\end{array}$ & 55 & 145 & 146 & 146 \\
\hline 4 & D3Mit17 & $\begin{array}{l}{ }^{*} \text { CATGGCTCCATGGTTCTTG } \\
\text { CCACGGAGAACAACTGAAGA }\end{array}$ & 57 & 196 & 196 & 196 \\
\hline 5 & D3Mit18 ${ }^{* *}$ & $\begin{array}{l}{ }^{*} \text { GAACAGTTCCCAGGTCCTCA } \\
\text { CTGCCTTTAAATTCTGTCACCC }\end{array}$ & 58 & 228 & 234 & 228 \\
\hline 6 & D3Mit29 & $\begin{array}{l}{ }^{*} \text { GATGAGAGATTCTGATGTGGAGG } \\
\text { CCAGCCTCAGTATCTCAAAACC }\end{array}$ & 60 & 145 & 145 & 145 \\
\hline 7 & D11Mit2 $^{* *}$ & $\begin{array}{l}{ }^{*} \text { TCCCAGAGGTCTCCAAGACA } \\
\text { CCACAGTGTGTGATGTCTTC }\end{array}$ & 58 & 103 & 102 & 103 \\
\hline 8 & D12Mit7 & $\begin{array}{l}{ }^{*} \text { CCGGGGATCTAAAACTACAT } \\
\text { TCTAATCTCAGCCCAATGGT }\end{array}$ & 55 & 104 & 104 & 104 \\
\hline 9 & D16Mit58 & $\begin{array}{l}\text { TCTTTTTTCATTGTTGTTATACACACA } \\
{ }^{*} \text { GGAACAAAAAACACGTGGCT }\end{array}$ & 55 & 158 & 158 & 158 \\
\hline 10 & D16Nds2 & $\begin{array}{l}\text { *ATTGGTGATCTTACAGAATAC } \\
\text { GTGGTCATGATATTCGTAGAT }\end{array}$ & 55 & 92 & 92 & 92 \\
\hline 11 & D5Mit259** & $\begin{array}{l}\text { ATGATCAAAACATTACTCCСTTCC } \\
{ }^{*} \text { ACAAAGTCAGGAGAAATGTGCA } \\
\end{array}$ & 53 & 133 & 131 & 133 \\
\hline 12 & D12Mit158 & $\begin{array}{l}{ }^{*} \text { CATTGGGCAATGGAATTTG } \\
\text { ATGAGAGAAAACCAGAAACAAAGG }\end{array}$ & 56 & 148 & 150 & 150 \\
\hline 13 & D13Mit148 & $\begin{array}{l}{ }^{*} \text { TGCTTGTGCTCATGCATACA } \\
\text { AAAGGAAGGTGGCAAGTAATAGG }\end{array}$ & 58 & 133 & 133 & 133 \\
\hline 14 & D15Mit175 & $\begin{array}{l}\text { ATAGCAACTAACAAAGACATACACACA } \\
{ }^{*} \text { ACCCATTGCAGTGTAAAATTCC }\end{array}$ & 57 & 175 & 175 & 175 \\
\hline 15 & D17Mit66 & $\begin{array}{l}{ }^{*} \text { GGCTTCCACACATGATTGC } \\
\text { TTCTGGGTCCATCATCACAA }\end{array}$ & 58 & 124 & 124 & 122 \\
\hline
\end{tabular}

precise content of the B6 genome is extremely important before use of the strain in research.

Inbred mouse strains have been found to be in high rate of divergence (Fitch \& Atchley, 1985), however, the mechanism of rapid evolution is still not understood. What appears to have happened is that, the current B6 dispersed in different breeders is not identical to each other in genetic background. The questions are why, how, and where did this occur? The present study results from limited commercial animal breeders, but it reflects potential risk in use of inbred mice with complicated genetic background and may be helpful to expound our previous hypothesis in type 2 diabetes mouse model (Niu et al, 2007). However, we cannot estimate exactly how many scientific discoveries resulted really from the genetic difference of the same moue strain other than from the experiments themselves.

Urgently, a strict practicable strategy to monitor the genetic background of inbred mice is expected especially for animal breeders. For researchers, it is not always sensible to attribute their variability in studies to environmental, epigenetic, or stochastic differences simply.

Acknowledgments: We are indebted to Gynecological Oncology Center, Peking University People's Hospital and Central Laboratory, Peking University People's Hospital for providing essential devices and enthusiastic services, and Ms. J. TIAN for microsatellite genotyping. We are also thankful to Ms. ZHANG Menglei for reading the paper carefully and correcting some spelling and typographical mistakes. 


\section{References:}

Benavides F, Stern MC, Glasscock E, DiGiovanni J, Coghlan LG, Conti CJ. 2000. Microsatellite DNA variants between the inbred SENCAR mouse strains [J]. Mol Carcinogen, 28: 191-195.

Berglund ED, Li CY, Poffenberger G, Ayala JE, Fueger PT, Willis SE, Jewell MM, Powers AC, Wasserman DH. 2008. Glucose metabolism in vivo in four commonly used inbred mouse strains [J]. Diabetes, 57: 1790-1799.

Burcelin R, Crivelli V, Dacosta A, Roy-Tirelli A, Thorens B. 2002. Heterogeneous metabolic adaptation of C57BL/6J mice to high-fat diet [J]. Am J Physiol Endocrinol Metab, 282: E834-E842.

Casellas J, Medrano JF. 2008. Within-generation mutation variance for litter size in inbred mice[J]. Genetics, 179: 2147-2155.

Crabbe JC, Wahlsten D, Dudek BC. 1999. Genetics of mouse behavior: interactions with laboratory environment[J]. Science, 284: 1670-1672.

Dallas JF. 1992. Estimation of microsatellite mutation rates in recombinant inbred strains of mouse [J]. Mamm Genome, 3: 452-456.

de Fourmestraux V, Neubauer H, PoussinC, Farmer P, Falquet L, Burcelin R, Delorenzi M, Thorens B. 2004. Transcript profiling suggests that differential metabolic adaptation of mice to a high fat diet is associated with changes in liver to muscle lipid fluxes[J]. J Biol Chem, 279: 50743-50753.

Fitch WM, Atchley WR. 1985. Evolution in inbred strains of mice appears rapid [J]. Science, 228: 1169-1175.

Li J, Wei H, Zhang Y, Zhang S. 2001a. Genetic monitoring of six strains of inbred mice by microsatellite DNA PCR with 40 pairs of primers [J]. Sichuan J Zool, 20: 119-122.
Li J, Zhang S, Wei H. 2001b. Genetic monitoring of the inbred strain of mice by microsatellite DNA PCR[J]. Acta Agric Boreali-occidentalis Sin, 10: 1-3.

Niu Y, Liang S, Wang X. 2007. Abnormal change in body weight and non-fasting blood glucose levels of mouse strain $\mathrm{C} 57 \mathrm{BL} / 6 \mathrm{~J}$ in generating type 2 diabetes model[J]. Zool Res, 28: 507-510.

Slingsby JH, Hogarth MB, Simpson E, Walport MJ, Morley BJ. 1995. New microsatellite polymorphisms identified between C57BL/6J, C57BL/10, and C57BL/KsJ inbred mouse strains[J]. Immunogenetics, 43: 72-75.

Specht CG, Schoepfer R. 2001. Deletion of the alpha-synuclein locus in a subpopulation of C57BL/6J inbred mice [J]. BMC Neuroscience, 2: 11-19.

Taft RA, Davisson M, Wiles MV. 2006. Know thy mouse [J]. Trends Genet, 22: 649-653

Van Oosterhout C, Hutchinson WF, Wills DPM, Shipley P. 2004. Micro-checker: software for identifying and correcting genotyping errors in microsatellite data[J]. Mol Ecol Notes, 4: 535-538.

Wang H, YueB, Liu S, He Z, Xing R. 2006. Evaluation of STR method for mice genetic monitoring[J]. Chin J Comp Med, 16: 135-138.

Watkins-Chow DE, Pavan WJ. 2008. Genomic copy number and expression variation within the C57BL/6J inbred mouse strain [J]. Genome Res, 18: 60-66.

Yeh FC, Boyle TJB. 1997. Population genetic analysis of codominant and dominant markers and quantitative traits [J]. Belg J Bot, 129: 157.

\section{(上接第 584 页)}

在欧洲和非洲, 斑[姬]淾比较常见, 行为研究资 料较多，又名 “欧洲斑姬叙”（ European Pied Flycatcher)。栖息环境为落叶林区、灌木丛，属于典 型的林鸟。非常好动, 喜欢朝尾和垂翅。善食飞虫, 如膜翅目、双翅目、鞘翅目 (甲虫)、鳞翅目等昆虫。 在树洞中营巢（也利用人工巢箱）, 产卵 5-7 枚。通

\section{参考文献:}

Cheng T. 1987. A Synopsis of the Avifauna of China [M]. Beijing: Science Press.

MacKinnon J, Phillipps K, He FQ . 2000. A Field Guide to the Birds of China [M]. New York: Oxford Univ Press.
常在北欧高纬度地带繁殖，至北非越冬，具有远距离 迁徙能力。在邻国哈萨克斯坦、蒙古和俄罗斯的西西 伯利亚都有零星的分布。根据地理位置和羽色分析, 在新疆昆仑山的这个新记录应该属于斑[姬]凃西伯利 亚亚种 (Ficedula hypoleuca sibirica)。

Ma M. 2001. A Checklist of the Birds in Xinjiang, China [M]. Beijing: Science Press.

Zheng GM. 2002. A Checklist on the Classification and Distribution of the Birds of the World [M]. Beijing: Science Press. 